Link article (Style APA): Vavryniv O. S. (2020). Empirical study of the professional empathy of future rescuers. Insight: the psychological dimensions of society, 4, 57-72. DOI: $10.32999 / 2663-970 X / 2020-4-4$

Link article (Style DSTU 8302: 2015): Vavryniv, O. S. Empirical study of the professional empathy of future rescuers. Insight: the psychological dimensions of society, 2020, 4, 57-72. DOI: $10.32999 / 2663-970 X / 2020-4-4$

UDC 159.922.27

\title{
Empirical study of the professional empathy of future rescuers
}

\author{
Емпіричне дослідження професійної емпатії \\ майбутніх рятувальників
}

Received: April 28, 2020 Accepted: October 30, 2020

\author{
Vavryniv Olena Stepanivna \\ Candidate of Psychological Sciences \\ Lviv State University of Life Safety, Ukraine \\ vavrynivolena@gmail.com, \\ ORCID 0000-0002-5166-6887
}

\author{
Вавринів Олена Степанівна \\ кандидат психологічних наук \\ Львівський державний університет \\ безпеки життєдіяльності, Україна \\ vavrynivolena@gmail.com, \\ ORCID 0000-0002-5166-6887
}

\begin{abstract}
The article analyzes the main views on the problem of working in special conditions and the peculiarities of the development of professional empathy of future rescuers. The purpose of the empirical research is to establish individual psychological correlatives of professional empathy of future rescuers. Methods: theoretical analysis and generalization; Freiburg multifactor personal questionnaire "FPI"; "Diagnosis of emotional intelligence" (N. Hall); "Balanced Emotional Empathy Scale BEES", A. Mehrabian - a modification of N. Epstein; "Diagnosis of the level of empathic abilities" V. Boiko; "Motivation for success" by T. Ehlers and "Diagnosis for motivation to avoid failures" by T. Ehlers; "SACS" (S. Hobfoll, adapted by N. Vodopyanova and O. Starchenkova); "Forecast" (assessment of neuropsychiatric instability); "Diagnosis of the risk readiness level” A. Schubert. Results. The social psychological features of the formation of professional empathy are described and the definition of the concept of "professional empathy of the rescuer" is given.
\end{abstract}

\begin{abstract}
Анотація
У статі проаналізовано основні погляди на проблему діяльності в особливих умовах та особливості розвитку професійної емпатії майбутніх рятувальників. Метою емпіричного дослідження $\epsilon$ встановлення індивідуально-психологічних корелятів професійної емпатії майбутніх рятувальників. Методи: теоретичне аналізування та узагальнення; багатофакторний особистісний опитувальник "FPI”; “Діагностика емоційного інтелекту” (Н. Холл); “Шкала емоційного відгуку” ("Balanced Emotional Empathy Scale - BEES”, A. Меграбяна модифікація Н. Епштейна); “Діагностика рівня емпатійних здібностей” В. Бойко; “Діагностика мотивації до досягнення успіху” Т. Елерса та “Діагностика мотивації уникнення невдач” Т. Елерса; "SACS” (S. Hobfoll, в адаптації Н. Водоп’янової і О. Старченкової); “Прогноз” (оцінка нервово-психічної нестійкості); “Діагностика рівня готовності до ризику” А. Шуберт. Результати. Описано соціально-психологічні особливості формування професійної емпатії та подано визначення поняття “професійна емпатії рятувальника". Встановлено, що учасникам дослідження притаманний високий рівень
\end{abstract}


It has been found that the study participants have a high level of empathy, high level of risk readiness, high level of motivation for success, medium level of motivation to avoid failure, high level of neuropsychiatric stability, high and medium level of spatial representations' ability to establish social contact, ability to control their emotions, self-motivation, sociability, balance, extroversion, openness and masculinity. Empathy correlates have also been established. High levels of empathy are closely correlated with indicators such as attitudes that promote or hinder empathy, penetrating empathy, risk readiness, high levels of motivation for success, sociability, masculinity, assertive actions, emotional awareness, high levels of neuropsychiatric stability, a moderately high level of motivation to avoid failure. Conclusions. Correlation analysis has found that empathy is positively influenced by education, namely the development of motivation to help others. The ability to empathize will promote positive adaptation in society and the establishment of social contacts. Cadets with a low level of empathy are aggressive and prone to cruelty, they do not seek to avoid failure or have certain internal fears.

Keywords: professional empathy, future rescuers, formation of professional empathy, components of professional empathy, correlation analysis of professional empathy.

\section{Introduction}

The role of empathy in personal development has been the subject of research for a long time. As a social psychological phenomenon, empathy significantly affects the personality as a whole, increases motivation, productivity and efficiency of activity of the person.

It is an important factor in individual and professional development of the person, in particular, the participants of socionomic professions. Empathy is a necessary condition for the development of emotional maturity of the personality and interpersonal understanding. It promotes humane relationships and altruistic behavior. Empathic compassion, involvement, is the motive for the choice and successful realization of a specialist in the helping professions, in particular, rescuers (Tarasova et al., 2017).

A special stressful factor for the professional activity of rescuers during the daily combat duty емпатійності, високий рівень готовності до ризику, високий рівень мотивації до досягнення успіху, середній рівень мотивації на уникнення невдач, високий рівень нервово-психічної стійкості, високий та середній рівні розвитку просторових уявлень, схильність до асертивних дій, вміння встановлювати соціальний контакт, здатність управляти своїми емоціями, самомотивованість, комунікабельність, врівноваженість, екстравертованість, відкритість та маскулінність. Також встановлено кореляти емпатії. Високий рівень емпатії має тісні кореляційні зв'язки з такими показниками, як настановлення, що сприяють або перешкоджають емпатії, проникаюча здатність до емпатії, готовність до ризику, високий рівень мотивації досягнення успіху, комунікабельність, маскулінність, асертивні дії, емоційна обізнаність, високий рівень НПС, помірно високий рівень мотивації уникнення невдач. Висновки. Кореляційним аналізуванням встановлено, що на емпатійність позитивно впливає виховання, а саме розвиток мотивації допомоги оточуючим. Здатність до емпатії сприятиме позитивній адаптації у суспільстві та встановленню соціальних контактів. Курсанти 3 низьким рівнем емпатії агресивні та схильні до жорстокості, не прагнуть уникати невдачі або ж мають певні внутрішні страхи.

Ключові слова: професійна емпатія, майбутні рятувальники, формування професійної емпатії, компоненти професійної емпатії, кореляційний аналіз професійної емпатії.

\section{Вступ}

Роль емпатії в особистісному розвитку тривалий час $\epsilon$ предметом наукових досліджень. Емпатія, як соціально-психологічний феномен, суттєво впливає на особистість в цілому, підвищує мотивацію, продуктивність та ефективність їі діяльності.

Емпатія $\epsilon$ важливим чинником індивідуального та професійного розвитку особистості, зокрема, у професіях соціономічного типу. Емпатія $\epsilon$ необхідною умовою розвитку емоційної зрілості особистості та міжособистісного взаєморозуміння. Емпатія сприяє розвитку гуманних відносин та альтруїстичного стилю поведінки. Емпатійне співчуття, співпереживання $\epsilon$ мотивом вибору та успішної реалізації фахівця у професіях допомагаючого типу, до яких, зокрема, належать рятувальники (Tarasova et al., 2017).

Особливим стресогенним чинником для професійної діяльності рятувальників під час

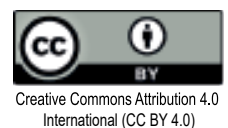


Empirical study of the professional empathy of future rescuers

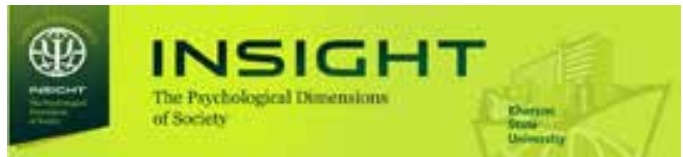

is a constant mode of anxious waiting. During the shift, an employee of the emergency rescue units of the SES is in a constant state of combat readiness to arrive at the scene in the event of a request to solve combat tasks and provide assistance to the injured persons. The "standby" mode and full combat readiness negatively affect both mental and physical health, as there are violations of the sleep-wake cycle (Vavryniv, 2020).

When researching the problem of psychological burnout in emergency workers, A. Kufliievskyi identifies external and internal factors of psychological burnout. External factors include: high responsibility for the performance of professional duties; chronically intense psychoemotional activity; destabilizing organization of activity; unfavorable psychological atmosphere of professional activity; psychologically complex contingent the specialist encounters during the localization of an emergency. Internal factors of professional burnout of rescuers include: emotional rigidity; moral defects and disorientation of the personality; intensive internalization (perception and experience) of the conditions of professional activity (Kufliievskyi, 2006).

Peculiarities of behavior in extreme conditions can be traced in its disorganization; inhibition of acquired skills; inadequate reactions to stimuli; reduced efficiency; deterioration of switching and distribution of attention; narrowing of the volume of perception; blackout; the appearance of impulsive actions; deterioration of productive thinking; dysmotility. There are also autonomic, psychophysiological and biochemical changes, in particular, an increase of leukocytes, ascorbic acid, corticosteroids in urine; disorders of heart rate, respiration, blood pressure. The same symptoms will occur in representatives of risky sports (Kuzikova et al., 2020; Pshenychna et al., 2019).

The ability to empathize is the practice of providing an emotional response to the experiences, thoughts and feelings of the object of empathy. Some scholars believe that empathy is the emotional ability to respond to signals that convey the emotional experience of another person. Others define empathy as a behavioral несення добового бойового чергування є постійний режим тривожного очікування. Під час своєї зміни працівник аварійно-рятувальних підрозділів ДСНС знаходиться в стані постійної бойової готовності, щоб у разі виклику прибути на місце події для вирішення бойових завдань та надання допомоги потерпілим. Режим "очікування" та повна бойова готовність негативно впливає на стан як психічного, так і фізичного здоров'я, позаяк мають місце порушення режиму сон-неспання (Вавринів, 2020).

А. Куфлієвський, досліджуючи проблему психологічного вигорання у працівників аварійно-рятувальних підрозділів, виділяє зовнішні та внутрішні чинники психологічного вигорання. Так, до зовнішніх чинників відносить: високу відповідальність за виконання професійних обов'язків; хронічно напружену психоемоційну діяльність; дестабілізуючу організацію діяльності; несприятливу психологічну атмосферу професійної діяльності; психологічно складний контингент, з яким фахівець зустрічається під час локалізації надзвичайної ситуації. До внутрішніх чинників професійного вигорання рятувальників включає: емоційну ригідність; моральні дефекти й дезорієнтацію особистості; інтенсивну інтеріоризацію (сприйняття й переживання) умов професійної діяльності (Куфлієвський, 2006).

Особливості поведінки в екстремальних умовах простежуються в їі дезорганізації; гальмуванні набутих навичок; неадекватних реакціях на подразники; зниженні працездатності; погіршенні переключення і розподілу уваги; звуження обсягу сприйняття; провалах пам'яті; появі імпульсивних дій; погіршенні продуктивного мислення; порушенні моторики. 3'являються також вегетативні, психофізіологічні та біохімічні зміни, зокрема, збільшення у сечі лейкоцитів, аскорбінової кислоти, кортикостероїдів; порушення частоти серцевих скорочень, дихання, кров'яного тиску. Такі ж ознаки будуть мати місце у представників ризиконебезпечних видів спорту (Kuzikova et al., 2020; Pshenychna et al., 2019).

Здатність до емпатії полягає у вмінні надати емоційну відповідь на переживання, думки та почуття об’єкта емпатії. Деякі науковці вважають, що емпатія - це емоційна здатність

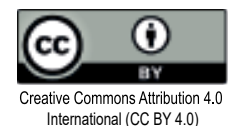

insight.stateuniversity.ks.ua ISSN 2663-970X 
ability that is traced to helping, facilitating and providing altruistic behavior in response to another person's experiences or problems. M.L. Hoffman views empathy as a biologically conditioned predisposition to altruistic behavior. In his writings, he emphasizes that sincere compassion generates altruistic motivation for help behavior (Hoffman, 2002).

As a motivating factor for help, empathy is also divided into certain forms of help behavior: the actual actions aimed at providing help; prosocial behavior, altruistic behavior. C. Batson formulated his "empathy - altruism" hypothesis. Its essence is that true altruistic human behavior, aimed at helping others, does not provide in return for any benefit or social encouragement, the growth of respect or self-esteem due to the provision of assistance, motivated by empathy (Batson, 1997).

Empathy of representatives of professions related to assistance can be studied in two ways: empathy as a factor in the successful implementation of professional activities and empathy as a motivating factor in choosing a profession. Also, compassion, involvement acts as a mediatory motive in the activity of workers of the positions connected with assistance, namely rescuers.

In medical practice, empathy is extremely necessary, it greatly affects the success of treatment and further favorable conditions of the disease. In the practice of doctors, empathy allows making more accurate and early diagnoses, and avoid unnecessary research, which allows achieving lasting results in the treatment process. Researchers who study emotional intelligence also emphasize the need for empathy in physicians (Halian, 2020).

However, unfortunately, there are no studies of the empathy of rescuers as the brightest representatives of the type of professions related to help.

Readiness to act in special and extreme conditions is determined by the presence of intrinsic motivation to provide assistance to people who need it. Empathic compassion and involvement can be called a motive-mediator in the activities of representatives of the extreme profile. реагувати на сигнали, що передають емоційний досвід іншого. Інші визначають емпатію як поведінкову здібність, яка простежується в допомозі, сприянні та альтруїстичній поведінці у відповідь на переживання чи проблеми іншої людини. М.-Л. Гофман розглядає емпатію як біологічно зумовлену схильність до альтруїстичної поведінки. У своїх працях він наголошує на тому, що щире співчуття (емпатія) породжує альтруїстичну мотивацію поведінки допомоги (Hoffman, 2002).

Також емпатія, як мотиваційний чинник допомоги, поділяється на певні форми поведінки допомоги: власне дії, спрямовані на надання допомоги; просоціальна поведінка, альтруїстична поведінка. Ч. Батсон сформулював свою гіпотезу “емпатія - альтруїзм". Суть іï полягає в тому, що справжня альтруїстична поведінка людини, спрямована на допомогу іншій, не передбачає у відповідь жодної вигоди чи соціального заохочення, зростання поваги чи самоповаги внаслідок надання допомоги, змотивоване саме емпатією (Batson, 1997).

Емпатію представників професій, пов'язаних 3 допомогою, можна досліджувати за двома напрямками: емпатія як чинник успішного здійснення професійної діяльності та емпатія як мотиваційний чинник вибору професії Також емпатійне співчуття, співпереживання виступає мотивом-посередником у діяльності представників професій, пов'язаних з допомогою, а саме рятувальників.

Емпатія в медичній практиці $є$ вкрай необхідною, неабияк впливає на успішність лікування та подальші сприятливі умови перебігу хвороби. Емпатія у практичній діяльності лікарів дозволяє ставити більш точні та ранні діагнози, й уникати зайвих досліджень, що дозволяє досягти стійких результатів у процесі лікування. Також науковці, які досліджують емоційний інтелект, наголошують про необхідність його наявності у медиків (Halian, 2020).

Проте, на жаль, зовсім відсутні дослідження емпатії рятувальників як найяскравіших представників типу професій, пов'язаних з допомогою.

Готовність до діяльності в особливих та екстремальних умовах визначається наявністю внутрішньої мотивації до надання допомоги 
Discussions are mostly about the characteristics of the emotional response, in particular, normative and situational, as empathy is considered an important factor in motivating help behavior. Also, the problem of empathy necessitates the need to identify various forms of care, in particular, prosocial, altruistic.

When talking about the relationship between empathy and help, it is important to emphasize such a phenomenon as empathic distress. Empathic distress is traced in the form of negative feelings and emotions due to contemplation of another person's suffering. High personal empathic distress is the motive for the emergence of help behavior (Batson et al., 2001).

S. Nartova-Bochaver believes that the basis of the help behavior is directly the readiness of the personality to help. Readiness implies the availability of certain personal resources: cognitive (analyzes the unfavorable situation in which another person is, understanding of what we can help and make the best decision); behavioral (assumes the ability to provide assistance) and motivation for assistance (inner desire to save a person from suffering). The concept of motivation for help is usually used in the context of the affective component of readiness for help as a motivational-affective sphere of personality. That is, it initiates an altruistic act. The research of this author shows that a necessary condition for help is the stability of altruistic intent (NartovaBochaver, 1992).

That is why we are convinced that professional empathy of the rescuer is a multilevel phenomenon, which is a set of emotional, cognitive and behavioral abilities of the rescuer, which causes intrinsic motivation to provide help.

Empathy can claim the professionally important quality of the rescuers' personality, as it contributes to the optimal acquisition of relevant professional skills and abilities. Also, the important components of educational and professional activities of students and cadets are the structure, variables and interdependence of factors of mental states of expectations (Popovych, Blynova, 2019; Shevchenko, 2019).

It will be useful to outline the social psychological features of the formation of professional empathy in view of the peculiarities of the future людям, які ї потребують. Мотивом-посередником у діяльності представників екстремального профілю впевнено можемо назвати емпатійне співчуття та співпереживання.

Дискусії стосуються здебільшого особливостей емоційного відгуку, зокрема, нормативного та ситуаційного, позаяк емпатія вважається важливим фактором мотивації допомагаючої поведінки. Також проблема емпатії задає потребу в необхідності виокремлення різноманітних форм допомоги, зокрема, просоціальної, альтруїстичної.

Ведучи мову про взаємозв'язок емпатії та допомоги, важливо наголосити на такому феномені, як емпатійний дистрес. Простежується емпатійний дистрес у вигляді негативних почуттів та емоцій внаслідок споглядання на страждання іншої людини. Високий особистісний емпатійний дистрес слугує мотивом виникнення поведінки допомоги (Batson et al., 2001).

С. Нартова-Бочавер вважає, що підгрунтям поведінки допомоги $є$ безпосередньо готовність особистості до прояву допомоги. Готовність передбачає наявність певних особистісних ресурсів: когнітивних (аналізується несприятлива ситуація, в якій знаходиться інша людина, розуміння того, чим ми можемо допомогти та приймаємо оптимальне рішення); поведінкових (передбачається наявність здібностей та можливості надання допомоги) та мотивації допомоги (внутрішнє бажання врятувати людину від страждань). Поняття мотивації допомоги зазвичай використовується в контексті афективного компонента готовності до допомоги як мотиваційно-афективної сфери особистості. Тобто ініціює альтруїстичний вчинок. Дослідження даного автора свідчать про те, що необхідною умовою надання допомоги $\epsilon$ стійкість альтруїстичного наміру (Нартова-Бочавер, 1992).

Саме тому ми переконані, що професійна емпатія рятувальника - це багаторівневий феномен, який є сукупністю емоційних, когнітивних та поведінкових здібностей особистості рятувальника, що викликає внутрішню мотивацію до надання допомоги.

Емпатія може претендувати на професійно важливу якість особистості рятувальників, позаяк вона сприяє оптимальному набуттю 
rescuers' activities. After all, they will contribute to the optimal development of professional skills and abilities of future rescuers. These include: primary ability to empathize; empathic experience; respect for the profession and selfesteem of the rescuer; regularity of assistance; obligation to provide assistance.

Thorough theoretical analysis allowed to identify the following components of professional empathy: cognitive, emotional, motivational and behavioral.

Summing up, we can talk about the importance of empathy of future rescuers. Empathetic cadets, future rescuers, will be more interested in learning special disciplines and honing their practical skills, as they will understand the level of their responsibility placed to save the injured population. In the future, as employees of the SES of Ukraine, a high level of empathy will encourage them to improve their skills.

The purpose of the empirical research is to establish individual psychological correlatives of professional empathy of future rescuers.

\section{Methodology and methods.}

To carry out a thorough study of any phenomenon, it is necessary to determine the system of factors that identify it. The research lasted from 2016 to 2018.

Based on theoretical analysis, it is established that empathy is not only a necessary condition for full interaction and communication between people, but also an important quality in the profession of the helping type. In our study, we held the view of empathy as a complex functional system that involved the interdependent unity of cognitive, emotional, motivational and behavioral components. Therefore, based on the basis of the model of theoretical and semantic components of professional empathy of future rescuers developed by us, we will try to carry out empirical research and determine the factors of formation of future rescuers' professional empathy.

To ensure an empirical study of the professional empathy of future rescuers in accordance with the selected components, a number of techniques were selected, including the following: Freiburg multifactor personal questionnaire "FPI"; відповідних професійних вмінь і навичок. Також важливими складовими навчально-професійної діяльності студентів та курсантів є структура, змінні і взаємозалежність чинників психічних станів очікувань (Popovych, Blynova, 2019; Shevchenko, 2019).

Доцільно буде окреслити соціально-психологічні особливості формування професійної емпатії з огляду на особливості діяльності майбутніх рятувальників. Адже саме вони сприятимуть оптимальному розвитку професійних навичок та вмінь майбутніх рятувальників. До них належать: первинна здатність до емпатії; емпатійний досвід; повага до професії та самоповага рятувальника; регулярність надання допомоги; обов'язковість надання допомоги.

Грунтовне теоретичне аналізування дозволило виокремити такі компоненти професійної емпатії: когнітивний, емоційний, мотиваційний та поведінковий.

Підсумовуючи, можемо говорити про важливість розвитку емпатії у майбутніх рятувальників. Курсанти - майбутні рятувальники, наділені емпатією, будуть з більшою цікавістю вивчати спеціальні дисципліни та відточувати практичні навички, позаяк розумітимуть рівень відповідальності, покладений на них за порятунок потерпілого населення. В майбутньому, будучи працівниками ДСНС України, високий рівень емпатії спонукатиме їх до підвищення професійної кваліфікації.

Метою емпіричного дослідження $\epsilon$ встановлення індивідуально-психологічних корелятів професійної емпатії майбутніх рятувальників.

\section{Методологія і методи}

Для здійснення грунтовного дослідження будь-якого явища необхідно визначити систему чинників, які його детермінують. Дослідження тривало з 2016 р. по 2018 р.

На основі теоретичного аналізування встановлено, що емпатія $\epsilon$ не лише необхідноюумовою для повноцінної взаємодії і спілкування між людьми, а й важливою якістю в професії допомагаючого типу. У нашому дослідження ми дотримувалися думки, що емпатія - це складна функціональна система, яка передбачає взаємозумовлену єдність когнітивного, емоційного, мотиваційного та поведінкового 
"Diagnosis of emotional intelligence" (N. Hall); "Balanced Emotional Empathy Scale - BEES", A. Mehrabian - a modification of N. Epstein); "Diagnosis of the level of empathic abilities" V. Boiko; "Diagnosis of motivation for success" by $\mathrm{T}$. Ehlers and "Diagnosis of motivation to avoid failures" by T. Ehlers; "SACS" (S. Hobfoll, adapted by N. Vodopyanova and O. Starchenkova); "Diagnosis of the risk readiness level" A. Schubert. The sample consists of 282 fourth-year cadets of Lviv State University of Life Safety.

Statistical data processing was performed using the computer program SPSS 20.0.

\section{Results and discussion}

Based on the results of the method "Diagnosis of the risk readiness level" by A. Schubert, it was found that most of the studied future rescuers had high indicators of risk readiness, namely $59.6 \%$ of the total sample. $26.9 \%$ of respondents were ready for risk depending on the situation, external and internal factors. Also, only $13.5 \%$ of respondents were overly cautious.

Future rescuers were mostly focused on success. The results of the methodology "Diagnosis of motivation for success" by T. Ehlers were distributed as follows: too high level $21.6 \%$, high - $34.8 \%$, medium - $28.7 \%$ and low $14.9 \%$. The results of the methodology "Diagnosis of motivation to avoid failure" by T. Ehlers gave grounds to claim that only $31.0 \%$ were motivated to avoid failure, of which $13.5 \%$ have too high level, and $17.4 \%$ - moderately high. The medium level of motivation to avoid failure was for $34.7 \%$ of cadets and low for $34.4 \%$.

Detailed results of the methodology "Strategic Approach to Coping Scale" ("SACS") are presented in Table 1 . The studied subjects mostly use active and prosocial strategies of behavior in stressful situations, in particular, establishing social contact $(32.0 \%)$ and assertive actions (26.0\%).

From the analysis of data from Table 1, we assume that cadets in stressful situations will not be able to control themselves, their emotional state and behavior. Such behavior will be demonstrated unconsciously. A significant number of future rescuers have low values in terms of "search for social support". Such results can be explained by the fact that most often they perceive this behavior компонентів. Тому на основі розробленої нами моделі теоретично-змістових компонентів професійної емпатії майбутніх рятувальників спробуємо здійснити емпіричне дослідження та визначити чинники формування професійної емпатії майбутніх рятувальників.

Для забезпечення емпіричного дослідження професійної емпатії майбутніх рятувальників у відповідності до виокремлених компонентів було підібрано ряд методик, зокрема такі: багатофакторний особистісний опитувальник "FPI"; “Діагностика емоційного інтелекту" (Н. Холл); “Шкала емоційного відгуку" ("Balanced Emotional Empathy Scale - BEES", A. Меграбяна - модифікація Н. Епштейна); “Діагностика рівня емпатійних здібностей” В. Бойко; "Діагностика мотивації до досягнення успіху" Т. Елерса та "Діагностика мотивації уникнення невдач” T. Елерса; "SACS” (S. Hobfoll, в адаптації Н. Водоп’янової і О. Старченкової); “Діагностика рівня готовності до ризику” А. Шуберт. Вибірка досліджуваних складає 282 курсанти четвертого курсу Львівського державного університету безпеки життєдіяльності.

Статистична обробка даних здійснювалась за допомогою комп'ютерної програми SPSS 20.0.

\section{Результати і дискусія}

На основі результатів методики “Діагностика рівня готовності до ризику" А. Шуберта встановлено, що більшість досліджуваних майбутніх рятувальників має високі показники готовності до ризику, а саме - 59.6\% усієї вибірки. $26.9 \%$ досліджуваних готові до ризику в залежності від ситуації, зовнішніх та внутрішніх чинників. Також тільки $13.5 \%$ респондентів демонструють надмірну обережність.

Майбутні рятувальники здебільшого спрямовані на досягнення успіху. Результати методики “Діагностика мотивації до досягнення успіху" Т. Елерс розподілилися наступним чином: надто високий рівень - 21.6\%, високий $-34.8 \%$, середній $-28.7 \%$ та низький $14.9 \%$. Результати методики "Діагностика мотивації уникнення невдач” Т. Елерса, дає підстави стверджувати, що тільки $31.0 \%$ вмотивовані на уникнення невдач, 3 них $13.5 \%$ - надто

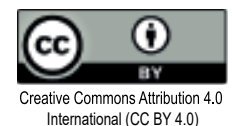


Table 1. The results of the study according to the method Strategic Approach to Coping Scale ("SACS")

Таблиця 1. Результати дослідження за методикою “Стратегії долання стресових ситуацій" ("SACS”)

\begin{tabular}{|c|c|c|c|c|}
\hline \multirow{2}{*}{$\begin{array}{l}\text { Coping strategies } \\
\text { Стратегії подолання }\end{array}$} & \multirow{2}{*}{$\begin{array}{l}\text { Models of behaviour } \\
\text { Моделі поведінки }\end{array}$} & \multicolumn{3}{|c|}{$\begin{array}{l}\text { Level of expression, \% } \\
\text { Рівні вираженості, \% }\end{array}$} \\
\hline & & $\begin{array}{c}\text { High } \\
\text { Високий }\end{array}$ & $\begin{array}{c}\text { Medium } \\
\text { Середній }\end{array}$ & $\begin{array}{c}\text { Low } \\
\text { Низький }\end{array}$ \\
\hline $\begin{array}{l}\text { Active } \\
\text { Активна }\end{array}$ & $\begin{array}{l}\text { Assertive actions } \\
\text { Асертивні дії }\end{array}$ & 18.0 & 46.5 & 35.5 \\
\hline \multirow{2}{*}{$\begin{array}{l}\text { Passive } \\
\text { Пасивна }\end{array}$} & $\begin{array}{l}\text { Precautions } \\
\text { Обережні дії }\end{array}$ & 13.5 & 45.7 & 40.8 \\
\hline & \begin{tabular}{|l|} 
Avoidance \\
Уникнення \\
\end{tabular} & 17.4 & 28.7 & 53.9 \\
\hline \multirow{2}{*}{$\begin{array}{l}\text { Prosocial } \\
\text { Просоціальна }\end{array}$} & $\begin{array}{l}\text { Search for social support } \\
\text { Пошук соціальної підтримки } \\
\end{array}$ & 11.4 & 45.7 & 42.9 \\
\hline & $\begin{array}{l}\text { Establishing social contact } \\
\text { Встановлення соціального контакту }\end{array}$ & 10.3 & 35.8 & 53.9 \\
\hline $\begin{array}{l}\text { Direct } \\
\text { Пряма }\end{array}$ & $\begin{array}{l}\text { Impulsive actions } \\
\text { Імпульсивні дії }\end{array}$ & 5.7 & 29.0 & 65.3 \\
\hline $\begin{array}{l}\text { Indirect } \\
\text { Непряма }\end{array}$ & $\begin{array}{l}\text { Manipulative actions } \\
\text { Маніпулятивні дії }\end{array}$ & 9.6 & 43.9 & 46.5 \\
\hline \multirow{2}{*}{$\begin{array}{l}\text { Antisocial } \\
\text { Асоціальна }\end{array}$} & $\begin{array}{l}\text { Antisocial actions } \\
\text { Асоціальні дії }\end{array}$ & 4.3 & 24.1 & 71.6 \\
\hline & Aggressive Агресивні діїactions & 9.9 & 27.7 & 62.4 \\
\hline
\end{tabular}

as a manifestation of weakness and insecurity. They also often have a desire to do some work on their own, while demonstrating their abilities and professional potential.

In coping behavior, emotional intelligence plays a resource role. After all, a high level of emotional intelligence allows to be more positive about the critical situation and better overcome stress. Cadets with a high level of emotional intelligence generally choose active and prosocial coping behavior strategies, and their risk of using destructive behavioral or avoidance strategies is reduced. It can be argued that emotional intelligence determines the choice of more adaptive strategies and behaviors of cadets. A low level of emotional intelligence will prevent cadets from controlling their own and others' emotions. As a result, future rescuers will use simpler coping strategies or destructive mechanisms of psychological protection.

The results of the study of emotional intelligence of future rescuers using the method of "Diagnosis of emotional intelligence" by $\mathrm{N}$. Hall showed that $32.6 \%$ of respondents had a high level of emotional intelligence, $39.4 \%$ of medium level and $28.0 \%$ of low level. More than half of the surveyed високий, а 17.4\% - помірно високий. Середній рівень мотивації на уникнення невдач у $34.7 \%$ курсантів та низький у $34.4 \%$.

Детальні результати методики “Стратегії долання стресових ситуацій" ("SACS") представлено в табл. 1. Досліджувані здебільшого використовують активні та просоціальні стратегії поведінки у стресових ситуаціях, зокрема, встановлення соціального контакту (32.0\%) і асертивні дії (26.0\%).

3 аналізування даних табл. 1, припускаємо, що курсанти в стресових ситуаціях не зможуть контролювати себе, свій емоційні стан і поведінку. Така поведінка буде демонструватися несвідомо. Значна кількість майбутніх рятувальників мають низькі значення за показником “пошук соціальної підтримки". Такі результати можна пояснити тим, що найчастіше дану поведінку вони сприймають як прояв слабкості та невпевненості. Також у них часто виникає бажання самостійно виконувати якусь роботу, при цьому демонструючи свої здібності та професійний потенціал.

У копінг-поведінці емоційний інтелект виконує ресурсну роль. Адже високий рівень емоційного інтелекту дозволяє більш позитивно 
Empirical study of the professional empathy of future rescuers

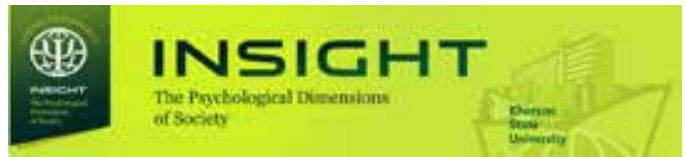

future rescuers had high and medium levels of emotional intelligence. Such rescuers will be able to achieve high results in the service, because according to I. Prykhodko, the success of the personality in professional activities often depends on the level of development of emotional intelligence. Emotional intelligence acquires special significance in the implementation of emergency rescue activities, as certain professionally important qualities of rescuers are the main components of their emotional intelligence (Prykhodko, 2014).

Regarding the development of partial emotional intelligence, the results were distributed as follows: a high level of emotional awareness was characteristic of $11.3 \%$ of respondents, $25.2 \%$ were able to control their emotions, $28.0 \%$ were capable of self-motivation, a high rate of empathy recorded $22.7 \%$ of cadets. $12.8 \%$ of respondents have high indicators of their ability to recognize other people's emotions. This means that the subjects are able to control their emotions. This is a very important indicator for their professional activity, as psychotraumatic situations can cause a surge of emotions. Future rescuers, who know how to control their emotions, will quickly take matters into their hands and start performing their duties.

Also, the cadets participated in the research show high self-motivation. This means that they are endowed with internal resources to intensify their actions in order to achieve their goals.

We present research of the descriptive characteristics of semantic psychological parameters by the method of "FPI" (Freiburg Personality Inventory ") in Table 2.

Based on the analysis of the results of the study of personal characteristics and qualities by the questionnaire "FPI" we see the studied cadets are mostly characterized as communicative, balanced, extroverted and open. The empirical section and the analyzed frequency characteristics allowed to state that the studied indicators of all psychological content parameters according to the FPI questionnaire did not deviate from the empirically established norms in other studies (Popovych et al., 2020a; 2020b; Striletska, 2017; Thoman et al., 2011).

Correlation analysis was used to establish relationships. Based on the correlation analysis, we ставитись до критичної ситуації та краще долати стрес. Курсанти 3 високим рівнем емоційного інтелекту здебільшого обирають активні та просоціальні стратегії копінг-поведінки, а також у них знижується ризик використання деструктивних поведінкових стратегій або стратегій уникнення. Можна стверджувати, що емоційний інтелект детермінує вибір більш адаптивних стратегій і способів поведінки курсантами. Низький рівень емоційного інтелекту заважатиме керувати своїми та чужими емоціями. Як наслідок, майбутні рятувальники використовуватимуть більш прості копінг-стратегії або деструктивні механізми психологічного захисту.

Результати дослідження емоційного інтелекту майбутніх рятувальників за допомогою методики "Діагностика емоційного інтелекту" Н. Холла показали, що у $32.6 \%$ респондентів спостерігається високий рівень емоційного інтелекту, у 39.4\% середній та у 28.0\% низький. Більша половина досліджуваних майбутніх рятувальників мають високі та середні показники емоційного інтелекту. Такі рятувальники зможуть досягнути високих результатів на службі, оскільки на думку I. Приходька, успішність особистості в професійній діяльності часто залежить від рівня розвитку емоційного інтелекту. Емоційний інтелект набуває особливої значущості у здійсненні аварійно-рятувальної діяльності, оскільки певні професійно-важливі якості рятувальників $\epsilon$ основними компонентами його емоційного інтелекту (Приходько, 2014).

Щодо розвитку парціального емоційного інтелекту, то результати розподілились наступним чином: високий рівень емоційної обізнаності характерний для $11.3 \%$ досліджуваних, $25.2 \%$ - вміють керувати своїми емоціями, $28.0 \%$ - здатні до самомотивації, за високим показником емпатії зафіксовано $22.7 \%$ курсантів. Високі показники здатності до розпізнавання емоцій інших людей у $12.8 \%$ респондентів. Це означає, що досліджувані мають здатність керувати своїми емоціями. Для їх професійної діяльності це дуже важливий показник, позаяк психотравматичні ситуації можуть спричинити сплеск емоцій. Майбутні рятувальники, які вміють керувати своїми емоціями, швидше візьмуть себе в руки

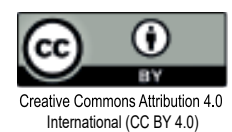


Table 2. Descriptive characteristics of semantic psychological parameters by the method of "FPI"

Таблиця 2. Описові характеристики змістових психологічних параметрів за методикою "FPI"

\begin{tabular}{|c|c|c|c|}
\hline $\begin{array}{c}\text { Scale } \\
\text { Шкала }\end{array}$ & $\mathbf{M}$ & $S_{x}$ & SD \\
\hline $\begin{array}{l}\text { Neuroticism } \\
\text { Невротичність }\end{array}$ & 4.57 & .16 & 1.63 \\
\hline $\begin{array}{l}\text { Spontaneous aggression } \\
\text { Спонтанна агресивність }\end{array}$ & 3.68 & .18 & 2.02 \\
\hline $\begin{array}{l}\text { Depressiveness } \\
\text { Депресивність }\end{array}$ & 3.70 & .15 & 1.79 \\
\hline $\begin{array}{l}\text { Irritability } \\
\text { Роздратованість }\end{array}$ & 4.48 & .15 & 1.71 \\
\hline $\begin{array}{l}\text { Sociability } \\
\text { Товариськість }\end{array}$ & 4.18 & .13 & 1.49 \\
\hline $\begin{array}{l}\text { Balance } \\
\text { Урівноваженість }\end{array}$ & 5.65 & .20 & 2.29 \\
\hline $\begin{array}{l}\text { Reactive aggression } \\
\text { Реактивна агресивність }\end{array}$ & 5.60 & .15 & 1.79 \\
\hline $\begin{array}{l}\text { Shyness } \\
\text { Сором'язливість }\end{array}$ & 5.59 & .15 & 1.79 \\
\hline $\begin{array}{l}\text { Openness } \\
\text { Відкритість }\end{array}$ & 6.18 & .15 & 1.69 \\
\hline $\begin{array}{l}\text { Extraversion / Introversion } \\
\text { Екстраверсія / Інтроверсія }\end{array}$ & 5.42 & .16 & 1.82 \\
\hline $\begin{array}{l}\text { Emotional instability } \\
\text { Емоційна лабільність }\end{array}$ & 5.34 & .18 & 1.86 \\
\hline $\begin{array}{l}\text { Masculinity / Femininity } \\
\text { Маскулінність / Фемінінність }\end{array}$ & 5.21 & .18 & 2.10 \\
\hline
\end{tabular}

Note: M - arithmetic mean; Sx - standard error; SD - standard deviation.

Примітка: M - середнє арифметичне; $\mathrm{S}_{\mathrm{x}}$ - стандартна похибка; SD - середнє квадратичне відхилення.

determined the nature of the internal connections of empathy development. Correlations of a very high level of empathy with indicators such as the intuitive channel of empathy $(\mathrm{r}=.481 ; \mathrm{p} \leq .01)$, identification in empathy $(\mathrm{r}=.325 ; \mathrm{p} \leq .01)$, risk readiness $(\mathrm{r}=.548 ; \mathrm{p} \leq .01)$, a high level of motivation for success $(\mathrm{r}=.421 ; \mathrm{p} \leq .01)$, femininity $(\mathrm{r}=.324 ; \mathrm{p} \leq .01)$, search for social support $(\mathrm{r}=.296 ; \mathrm{p} \leq .01)$ have been found. Cadets with a high level of empathy are mostly motivated for success, have high level of spatial representations, are ready to take risks and have a high educational score. These results indicate that they are ready to perform their work with quality and at a high professional level.

High levels of empathy are closely correlated with indicators such as attitudes that promote or hinder empathy ( $\mathrm{r}=.491 ; \mathrm{p} \leq .01)$, penetrating ability to empathize $(r=.316 ; \mathrm{p} \leq .01)$, riskreadiness та приступлять до виконання службових завдань.

Також досліджувані курсанти демонструють високі показники самомотивації. Це говорить про те, що вони наділені внутрішніми ресурсами для активізації своїх дій з метою досягнення поставлених цілей.

Подамо дослідження описових характеристик змістових психологічних параметрів за методикою "FPI" ("Freiburg Personality Inventory”) у табл. 2.

На підставі аналізування результатів дослідження особистісних властивостей та якостей за опитувальником “FPI” бачимо, що досліджувані курсанти здебільшого характеризуються як комунікативні, врівноважені, екстравертовані та відкриті. Проведений емпіричний зріз та проаналізовані частотні характеристики дозволили констатувати, що досліджувані 
Empirical study of the professional empathy of future rescuers

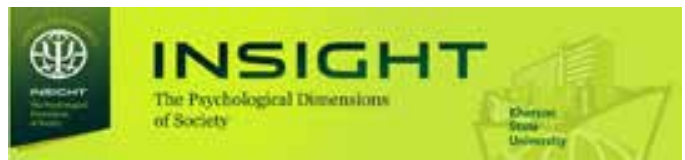

$(\mathrm{r}=.662 ; \mathrm{p} \leq .01)$, a high level of motivation for success $(\mathrm{r}=.433 ; \mathrm{p} \leq .01)$, sociability $(\mathrm{r}=.262$; $\mathrm{p} \leq .05)$, masculinity ( $\mathrm{r}=.297 ; \mathrm{p} \leq .01)$, assertive actions $(\mathrm{r}=.378 ; \mathrm{p} \leq .01)$, emotional awareness $(\mathrm{r}=.298 ; \mathrm{p} \leq .01)$, a high level of neuropsychaitric stability $(\mathrm{r}=.399 ; \mathrm{p} \leq .01)$. There are identified inverse correlations of high level of empathy with the indicator "moderately high level of motivation to avoid failures" $(\mathrm{r}=.324 ; \mathrm{p} \leq .01)$ combined with the positive relationship of the indicator "assertive actions" allow us to define that the cadets will confidently overcome both professional and life obstacles. Negative correlation with the indicator "emotional instability" $(\mathrm{r}=-.351 ; \mathrm{p} \leq .01)$ suggests that cadets with a high level of empathy are not prone to mood swings, resistant to the development of depression or neurasthenia (as evidenced by the positive correlation with the indicator "in high level of neuropsychiatric stability").

The normal (medium) level of empathy has direct correlation with such indicators as the rational channel of empathy $(r=.324 ; \mathrm{p} \leq .01)$, intuitive channel of empathy $(r=.378$; $p \leq .01)$, a high level of motivation for success ( $r=.148$ *; $\mathrm{p} \leq .05$ ), a medium level of motivation for success $(\mathrm{r}=.314 ; \mathrm{p} \leq .01)$, spontaneous aggression $(\mathrm{r}=.228 ; \mathrm{p} \leq .05)$ irritability $(\mathrm{r}=.273 * ; \mathrm{p} \leq .05)$, masculinity $(\mathrm{r}=.348 ; \mathrm{p} \leq .01)$, assertive actions $(\mathrm{r}=.456 ; \mathrm{p} \leq .01)$. The correlation of the middle level of empathy with such channels of empathy as rational and intuitive allows us to conclude that the manifestation of assistance by such cadets is based on the work of these channels. Such cadets are characterized by a focus on the object of empathy, namely, the essence of the problem and behavior. They have a spontaneous interest in the problem situation without specific motivation and logic. Cadets with a pronounced intuitive channel of empathy operate in conditions of lack of information about a person based on experience.

Low level of empathy has positive correlations with such indicators as medium level of readiness for risk ( $\mathrm{r}=.341 ; \mathrm{p} \leq .01)$, moderately high level of motivation to avoid failures $(\mathrm{r}=.248$; $\mathrm{p} \leq .05)$, spontaneous aggression $(\mathrm{r}=.321 ; \mathrm{p} \leq .01)$, depressiveness $(\mathrm{r}=.321 ; \mathrm{p} \leq .01)$, reactive aggression $(\mathrm{r}=.315 ; \mathrm{p} \leq .01)$, manipulative показники всіх психологічних змістових параметрів за опитувальником "FPI" не відхиляються від емпірично встановлених норм у інших дослідженнях (Popovych et al., 2020a; 2020b; Striletska, 2017; Thoman et al., 2011).

Для встановлення зв'язків було використано кореляційний аналіз. На основі кореляційного аналізу нами було визначено характер внутрішніх зв'язків розвитку емпатії. Кореляційні зв'язки дуже високого рівня емпатії 3 такими показниками, як інтуїтивний канал емпатії ( $\mathrm{r}=.481 ; \mathrm{p} \leq .01)$, ідентифікація в емпатії ( $\mathrm{r}=.325 ; \mathrm{p} \leq .01)$, готовність до ризику $(\mathrm{r}=.548 ; \mathrm{p} \leq .01)$, високий рівень мотивації досягнення успіху ( $\mathrm{r}=.421 ; \mathrm{p} \leq .01)$, фемінність $(\mathrm{r}=.324 ; \mathrm{p} \leq .01)$, пошук соціальної підтримки ( $\mathrm{r}=.296 ; \mathrm{p} \leq .01)$. Курсанти з високим рівнем емпатії здебільшого вмотивовані на досягнення успіху, мають високий рівень просторових уявлень, готові ризикувати та мають високий навчальний бал. Такі результати говорять про те, що вони готові виконувати свою роботу якісно та на високому професійному рівні.

Високий рівень емпатії має тісні кореляційні зв'язки 3 такими показниками, як настановлення, що сприяють або перешкоджають емпатії ( $\mathrm{r}=.491 ; \mathrm{p} \leq .01)$, проникаюча здатність до емпатії $(\mathrm{r}=.316 ; \mathrm{p} \leq .01)$, готовність до ризику $(\mathrm{r}=.662 ; \mathrm{p} \leq .01)$, високий рівень мотивації досягнення успіху $(\mathrm{r}=.433 ; \mathrm{p} \leq .01)$, комунікабельність $(\mathrm{r}=.262 ; \mathrm{p} \leq .05)$, маскулінність $(\mathrm{r}=.297 ; \mathrm{p} \leq .01)$, асертивні дії $(\mathrm{r}=.378 ; \mathrm{p} \leq .01)$, емоційна обізнаність ( $\mathrm{r}=.298 ; \mathrm{p} \leq .01)$, високий рівень НПС $(\mathrm{r}=.399 ; \mathrm{p} \leq .01)$. Виокремленні обернені зв'язки високого рівня емпатії із показником "помірно високий рівень мотивації уникнення невдач" $(\mathrm{r}=-.324 ; \mathrm{p} \leq .01)$ у поєднанні з позитивним зв'язком показника “асертивні дії” дозволяють говорити про те, що курсанти із впевненістю долатимуть як професійні, так і життєві перешкоди. Негативний зв'язок із показником “емоційна лабільність" ( $\mathrm{r}=-.351 ; \mathrm{p} \leq .01)$ дозволяє стверджувати про те, що курсанти із високим рівнем емпатії не схильні до перепадів настрою, стійкі до розвитку депресії чи неврастенії (про що говорить також позитивна кореляція з показником “високий рівень НПС”).

Нормальний (середній) рівень емпатії має прямі зв'язки з такими показниками, як

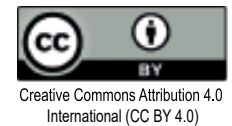

insight.stateuniversity.ks.ua ISSN 2663-970X 
actions ( $\mathrm{r}=.317 ; \mathrm{p} \leq .01)$, aggressive actions $(\mathrm{r}=.318 ; \mathrm{p} \leq .01)$. Based on the results, we can say that cadets with low levels of empathy often show a depressed mood, complain about problems in order to manipulate others, to provide them with help, support and compassion, so they themselves are not too prone to empathy.

A very low level of empathy is positively correlated with indicators such as: too cautious ( $\mathrm{r}=.352 ; \mathrm{p} \leq .01)$, a moderately high level of motivation to avoid failures $(\mathrm{r}=.374 ; \mathrm{p} \leq .01)$, neuroticism ( $\mathrm{r}=.352 ; \mathrm{p} \leq .01)$, depressiveness $(\mathrm{r}=.389 ; \mathrm{p} \leq .01)$, introversion $(\mathrm{r}=.293 ; \mathrm{p} \leq .01)$, manipulative actions $(\mathrm{r}=.368 ; \mathrm{p} \leq .01)$, antisocial action $(\mathrm{r}=.392 ; \mathrm{p} \leq .01)$. We also have inverse correlations with indicators: risk readiness $(\mathrm{r}=-.355 ; \mathrm{p} \leq .01)$, high level of motivation for success $(r=.287 ; p \leq .01)$, femininity $(r=-.329$; $\mathrm{p} \leq .01)$. These results suggest that cadets with low levels of empathy are aggressive and prone to cruelty, do not take risks avoiding failure, or have certain internal fears. When problems arise, they may experience frustration.

\section{Conclusions}

It is empirically researched and identified that cadets have the following properties and qualities: high, medium and low levels of empathy, intuitive channel of empathy, channel of settings that promote / hinder empathy, channel of identification in empathy, risk readiness, high level of motivation to achieve success, medium and low levels of motivation to avoid failure, high and normal levels of neuropsychological stability, high and medium levels of the development of spatial representations, propensity to assertive actions, ability to establish social contact, desire to receive social support, ability to manage their emotions, self-motivation, sociability, balance, extroversion, openness and masculinity.

Correlation analysis has found that empathy is positively influenced by education, namely the development of motivation to help others. The ability to empathize will promote positive adaptation in society and the establishment of social contacts. Cadets with the medium level of empathy, willingness to take risks and a strategy of "assertive action" determine the readiness to carry out activities in special conditions раціональний канал емпатії $(\mathrm{r}=.324 ; \mathrm{p} \leq .01)$, інтуїтивний канал емпатії $(\mathrm{r}=.378 ; \mathrm{p} \leq .01)$, високий рівень мотивації досягнення успіху ( $\left.\mathrm{r}=.148^{*} ; \mathrm{p} \leq .05\right)$, середній рівень мотивації досягнення успіху $(\mathrm{r}=.314 ; \mathrm{p} \leq .01)$, спонтанна агресивність $(\mathrm{r}=.228 ; \mathrm{p} \leq .05)$ дратівливість $\left(\mathrm{r}=.273^{*} ; \mathrm{p} \leq .05\right)$, маскулінність $(\mathrm{r}=.348$; $\mathrm{p} \leq .01)$, асертивні дії ( $\mathrm{r}=.456 ; \mathrm{p} \leq .01)$. Взаємозв'язок середнього рівня емпатії з такими каналами емпатії, як раціональний та інтуїтивний, дозволяють зробити висновки, що прояв допомоги такими курсантами здійснюється на основі роботи даних каналів. Такі курсанти характеризуються спрямованістю уваги на об’єкті емпатії, а саме, на суть його проблеми та поведінку. До проблемної ситуації у них виникає спонтанний інтерес без конкретної мотивації та логіки. Курсанти з вираженим інтуїтивним каналом емпатії діють за умов дефіциту інформації про людину на основі досвіду.

Низький рівень емпатійності має позитивні кореляційні зв'язки з такими показниками, як середній рівень готовності до ризику ( $\mathrm{r}=.341$; $\mathrm{p} \leq .01)$, помірно високий рівень мотивації уникнення невдач $(\mathrm{r}=.248 ; \mathrm{p} \leq .05)$, спонтанна агресивність $(\mathrm{r}=.321 ; \mathrm{p} \leq .01)$, депресивність $(\mathrm{r}=.321 ; \mathrm{p} \leq .01)$, реактивна агресивність $(\mathrm{r}=.315 ; \mathrm{p} \leq .01)$, маніпулятивні дії $(\mathrm{r}=.317$; $\mathrm{p} \leq .01)$, агресивні дії ( $\mathrm{r}=.318 ; \mathrm{p} \leq .01)$. На основі отриманих результатів можемо стверджувати, що курсанти з низьким рівнем емпатії часто проявляють депресивні настрої, скаржаться на проблеми 3 метою маніпулювати оточуючими, з метою надання їм допомоги, підтримки та співчуття, тому самі не надто схильні до співпереживання.

Дуже низький рівень емпатії позитивно корелює з такими показниками, як: занадто обережні ( $\mathrm{r}=.352 ; \mathrm{p} \leq .01)$, надто високий рівень мотивації уникнення невдач $(\mathrm{r}=.374$; $\mathrm{p} \leq .01)$, невротичність ( $\mathrm{r}=.352 ; \mathrm{p} \leq .01)$, дратівливість ( $\mathrm{r}=.389 ; \mathrm{p} \leq .01)$, інтроверсія ( $\mathrm{r}=.293 ; \mathrm{p} \leq .01)$, маніпулятивні дії $(\mathrm{r}=.368$; $\mathrm{p} \leq .01)$, асоціальні дії ( $\mathrm{r}=.392 ; \mathrm{p} \leq .01)$. Також маємо обернені кореляційні зв'язки з показниками: готовності до ризику ( $\mathrm{r}=-.355 ; \mathrm{p} \leq .01)$, високого рівня мотивації досягнення успіху $(\mathrm{r}==.287 ; \mathrm{p} \leq .01)$, фемінності $(\mathrm{r}=-.329 ; \mathrm{p} \leq .01)$.

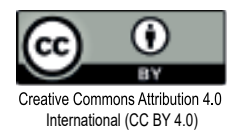


Empirical study of the professional empathy of future rescuers

and confidence in combat missions. Cadets with a low level of empathy often show a depressed mood, complain about problems in order to manipulate others, to provide them with help, support and compassion, so they are not too prone to empathy. Cadets with a low level of empathy are aggressive and prone to cruelty, they do not seek to avoid failure or have certain internal fears.

We see the study of the role of empathy in the personality structure of representatives of other professions of the helping type as promising as well as disclosure of age and gender features of this phenomenon at different stages of professionalization of the personality.

\section{References}

Batson, Ch. D. (1997). Self-other merging and the empathy-altruism hypothesis: Reply to Neuberg et al. Journal of Personality and Social Psychology, 73(3), 517-522.

Batson, C. D. \& Ahmad, N. (2001). Empathy-induced altruism in a prisoner's dilemma II: What is the target of empathy has defected? European Journal of Social Psychology, 25-36.

Hoffman, M. L. (2002). Empathy and Moral Development: Implications for Caring and Justice. New York: New York University Press.

Halian, A., Halian, I., Burlakova, I., Shevchenko, R., Lappo, V., Zhigarenko, I., et al. (2020). Emotional Intelligence in the Structure of Adaptation Process of Future Healthcare Professionals, Revista Inclusiones, $7(3), 447-460$.

Kufliievskyi, A. S. (2006). Social psychological determinants of the development of the "burnout" syndrome among employees of fire and rescue units of the Ministry of Emergencies of Ukraine. Extended abstract of Candidate's thesis. Kharkiv.

Kuzikova, S., Kuzikov, B., Shcherbak, T., Blynova, O., Vavryniv, O., Khmiliar, O. et al. (2020). Research of predisposition to risk of participants of extreme sports. Revista Inclusiones, 7 num Especial, 43-58.

Nartova-Bochaver, S. K. (1992). Experimental study of situational variability of aid motivation. Psychological Journal, 15-23.

Popovych, I. S. \& Blynova, O. Ye. (2019). The Structure, Variables and Interdependence of the Factors of Mental States of Expectations in Students' Academic and Professional Activities. The New Educational Review, 55 (1), 293-306. DOI: $10.15804 /$ tner.2019.55.1.24

Popovych, I., Kononenko, O., Kononenko, A., Stynska, V., Kravets, N., Piletska, L. et al. (2020a). Research of the Relationship between Existential Anxiety

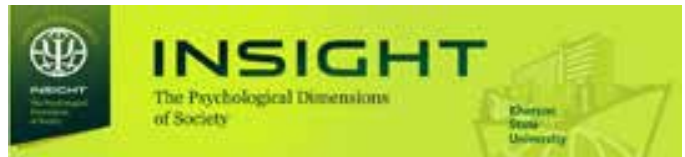

Такі результати дозволяють говорити про те, що курсанти $з$ низьким рівнем емпатії агресивні та схильні до жорстокості, не ризикують 3 метою уникнути невдачі або ж мають певні внутрішні страхи. При виникненні проблем у них може спостерігатися фрустрація.

\section{Висновки}

Емпірично досліджено i встановлено, що у курсантів яскраво виражені такі властивості та якості: високий, нормальний та низький рівні емпатійності, інтуїтивний канал емпатії, канал настановлень, що сприяють / перешкоджають емпатії, канал ідентифікації в емпатї̈, готовності до ризику, високий рівень мотивації до досягнення успіху, середній та низький рівні мотивації на уникнення невдач, високий та нормальний рівні нервово-психічної стійкості, високий та середній рівні розвитку просторових уявлень, схильність до асертивних дій, вміння встановлювати соціальний контакт, бажання отримати соціальну підтримку, здатність керувати своїми емоціями, самомотивованість, комунікабельність, врівноваженість, екстравертованість, відкритість та маскулінність.

Кореляційним аналізуванням встановлено, що на емпатійність позитивно впливає виховання, а саме розвиток мотивації допомоги оточуючим. Здатність до емпатії сприятиме позитивній адаптації у суспільстві та встановленню соціальних контактів. У курсантів із середнім рівнем емпатії, готовністю до ризику та стратегією “асертивні дії” зумовлюється готовність до здійснення діяльності в особливих умовах та впевненість у виконанні бойових завдань. Курсанти 3 низьким рівнем емпатії часто демонструють депресивні настрої, скаржаться на проблеми з метою маніпулювати оточуючими, з метою надання їм допомоги, підтримки та співчуття, тому не надто схильні до співпереживання. Курсанти з низьким рівнем емпатії агресивні та схильні до жорстокості, не прагнуть уникати невдачі або ж мають певні внутрішні страхи.

Перспективним вбачаємо вивчення ролі емпатії у структурі особистості представників інших професій допомагаючого типу; розкритті вікових та гендерних особливостей цього феномену на різних етапах професіоналізації особистості.

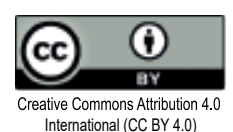


and the Sense of Personality's Existence. Revista Inclusiones, 7 num Especial, 41-59.

Popovych, I., Tkach, T., Sirko, R., Rudenko, L., Sokolova, H., Slobodianyk, V. et al. (2020b). Research on Mental States of Anxiety of First-Year Cadets of the University of Life Safety. Revista Inclusiones, 7 num Especial, 264-278.

Prykhodko, I. I. (2014). Psychological security of personnel of extreme activities (on the example of servicemen of the internal troops of MIA of Ukraine). Extended abstract of Doctor's thesis. Kharkiv, 2014.

Pshenychna, L., Kuzikova, S., Shcherbak, T., Kondratyuk, S., Petrenko, S. \& Skyba, O. (2019). Phenomenon of nervous mental stability in extreme sports. Journal of Physical Education and Sport, 19(4), 1349-1354.

Shevchenko, A. V. (2019). Research on the correlation between social desirability and value orientations in adolescence". Insight: the psychological dimensions of society, 1, 90-94. DOI: 10.32999/2663970X/2019-1-14

Striletska, I. I. (2017). The Specificity and Nature of the Relationship between Anxiety and Social Intelligence of Students of Different Specialties. Nauka and osvita, 1, 21-28. Retrieved from: DOI: $10.24195 / 2414-4665-2017-1-4$

Tarasova S. I., Dukhina, T. N., Limonova, O. O., Kolesnikova, T. V., Makhova, I. N. Socio-psychological adaptation of first-year university students. Revista ESPACIOS, 38(56), 2017: 35.

Thoman, D., Smith, J. \& Silvia, P. (2011). The resource replenishment function of interest. Social Psychological and Personality Science, 2, 592-599. DOI: $10.1177 / 19485506114025$

Vavryniv, O. S. (2020). Social and psychological features of the formation of professional empathy of future rescuers. Extended abstract of Candidate's thesis. Sievierodonetsk.

\section{Список використаних джерел}

Batson Ch. D. Self-other merging and the empathy-altruism hypothesis: Reply to Neuberg et al. Journal of Personality and Social Psychology. 1997. Vol. 73(3). P. 517-522.

Batson C. D., Ahmad N. Empathy-induced altruism in a prisoner's dilemma II: What is the target of empathy has defected? European Journal of Social Psychology, 2001. C. 25-36.

Hoffman M. L. Empathy and Moral Development: Implications for Caring and Justice. New York: New York University Press, 2002. 342 p.

Halian A., Halian I., Burlakova I., Shevchenko R., Lappo V., Zhigarenko I., Popovych I. Emotional Intelligence in the Structure of Adaptation Process of Future Healthcare Professionals, Revista Inclusiones, 2020. Vol: 7 num 3, P. 447-460.

Куфлієвський А. C. Соціально-психологічні детермінанти розвитку синдрому “вигоряння" серед працівників пожежно-рятувальних підрозділів МНС України: автореф. дис. на здобуття наук. ступеня канд. псих. наук: спец. 19.00.19 "Психологія діяльності в особливих умовах". Харків, 2006. 20 с.

Kuzikova, S., Kuzikov, B., Shcherbak, T., Blynova, O., Vavryniv, O., Khmiliar, O., Popovych, I. (2020). Research of predisposition to risk of participants of extreme sports. Revista Inclusiones, Vol: 7 num Especial, P. 43-58.

Нартова-Бочавер С. К. Экспериментальное исследование ситуационной изменчивости мотивации помощи. Психологический журнал. Москва. 1992. C. 15-23.

Popovych I. S., Blynova, 0. Ye. The Structure, Variables and Interdependence of the Factors of Mental States of Expectations in Students' Academic and Professional Activities. The New Educational Review, 2019, № 55 (1), P. 293-306. DOI: $10.15804 /$ tner.2019.55.1.24

Popovych, I., Kononenko, O., Kononenko, A., Stynska, V., Kravets, N., Piletska, L., Blynova, O. (2020a). Research of the Relationship between Existential Anxiety and the Sense of Personality's Existence. Revista Inclusiones, Vol: 7 num Especial. P. 41-59.

Popovych, I., Tkach, T., Sirko, R., Rudenko, L., Sokolova, H., Slobodianyk, V. \& Blynova, O. (2020b). Research on Mental States of Anxiety of First-Year Cadets of the University of Life Safety. Revista Inclusiones, Vol: 7 num Especial. P. 264-278.

Приходько I. I. Психологічна безпека персоналу екстремальних видів діяльності (на прикладі військовослужбовців внутрішніх військ MBC України): автореф. дис. на здобуття наук. ступеня доктора псих. наук: спец. 19.00.09 “Психологія діяльності в особливих умовах. Харків, 2014. 40 с. 
Pshenychna L., Kuzikova S., Shcherbak T., Kondratyuk S., Petrenko S., Skyba O. Phenomenon of nervous mental stability in extreme sports. Journal of Physical Education and Sport, 2019, Vol: 19 num 4. P. 1349-1354.

Shevchenko, A. V. Research on the correlation between social desirability and value orientations in adolescence". Insight: the psychological dimensions of society, № 1, 2019: P. 90-94. DOI: 10.32999/2663970X/2019-1-14

Striletska I. I. The Specificity and Nature of the Relationship between Anxiety and Social Intelligence of Students of Different Specialties. Nauka and osvita, № 1, 2017. P. 21-28. Retrieved from: DOI: 10.24195/2414-4665-2017-1-4

Tarasova S. I., Dukhina, T. N., Limonova, O. O., Kolesnikova, T. V., Makhova, I. N. Socio-psychological adaptation of first-year university students. Revista ESPACIOS, № 38(56), 2017: 35.

Thoman, D., Smith, J. \& Silvia, P. The resource replenishment function of interest. Social Psychological and Personality Science, № 2, 2011: P. 592-599. DOI: $10.1177 / 19485506114025$

Вавринів О. С. Соціально-психологічні особливості формування професійної емпатії майбутніх рятувальників: автореф. дис. на здобуття наук. ступеня канд. психол. наук: 19.00.05 “Соціальна психологія; психологія соціальної роботи”. Східноукраїнський національний університет імені Володимира Даля МОН України. Сєвєродонецьк, 2020. 22 с. 